\title{
OPTIMIZATION OF PRODUCTION PROCESS, CHARACTERIZATION AND ENGINE TESTING OF WASTE COOKING OIL BIODIESEL
}

\section{HILTON MAVERENGO \& FREDDIE L. INAMBAO}

Department of Mechanical Engineering, University of KwaZulu-Natal, Durban, South Africa

\begin{abstract}
This paper analyzes the suitability of mixed waste cooking oil (WCO)biodiesel as a viable fuel for diesel engines. WCO feedstock was purchased from a Enfields Chemicals a waste cooking oil buying firm based in Durban, boiled and cleaned to remove food particles and water. The oil was then evaluated for free fatty acid (FFA) composition and acid value and other physiochemical properties. The WCO acid value was found to be higher than the stipulated value for a single-step process hence a two-step production method of esterification and transesterification was instituted. Esterification was performed using sulphuric acid and methanol at a molar ratio of 9:1, 1 wt\% $\mathrm{H}_{2} \mathrm{SO}_{4}, 60{ }^{\circ} \mathrm{C}$ for 90 minutes until it became $0.688 \mathrm{mg}$ of $\mathrm{KOH}$ down from an initial value $8.67 \mathrm{mg}$ of $\mathrm{KOH}$. Thereafter homogenous alkali transesterification was performed with a methanol molar ratio of 6:1, 1 wt\% $\mathrm{NaOH}$ and temperature $60{ }^{\circ} \mathrm{C}$ for 60 minutes. Four factors selected for optimization were: molar ratio, catalysts concentration, reaction time and reaction temperature. The process parameters were optimized using a combination of Taguchi method using the MINI TAB-16 programming tool and ANOVA test. A total of 27 experiments were performed by varying the process parameters and manipulation of the $S / N$ ratio. The best conditions found were molar ratio of $7: 1$, temperature of $65^{\circ} \mathrm{C}$, catalyst concentration of $1.5 w \%$ and reaction time of 80 minutes. In terms of influence on yield the ranking was: reaction temperature, catalysts concentration, molar ratio and reaction time. The optimal parameters resulted in an increase in yield from 93\% to $96 \%$. The biodiesel was property evaluated and compared with fossil diesel (FD) using ASTM D6751 standards. Four fuel samples namely,FD fuel, WCO100, WCO20 and WCO40 were formulated and tested in a single cylinder Kirloskar engine for performance and emissions behavior. The results showed a maximum reduction of BTE of $17.8 \%$ with WCO100 and a BSFC increase of $23.7 \%$ compared with FD fuel. Emission parameters revealed a reduction in $\mathrm{CO}$ of $62.5 \%$, UBHC of $27.2 \%$ and smoke opacity of $34.45 \%$. However, an increase in $\mathrm{CO}_{2}$ of $28.43 \%$ and $\mathrm{NO}_{X}$ of $27.2 \%$ were determined when compared with FD fuel. The researchers concluded that WCO biodiesel can be utilized as an alternative fuel for diesel engines as its properties conform to ASTM D6751 and EN14214 and its combustion and emission behavior showed similar trends to those of FD fuel.

KEYWORDS: Waste Cooking Oil Biodiesel, Taguchi Method, process parameters, engine performance, exhaust emissions.
\end{abstract}

Received: Jan 11, 2021; Accepted: Jan 31, 2021; Published: Mar 08, 2021; Paper Id.: IJMPERDAPR202112 


\section{NOMENCLATURE AND ABBREVIATIONS}

\begin{tabular}{|c|c|c|c|}
\hline \multicolumn{2}{|c|}{ ANOVA Analysis of Variance } & \multirow{2}{*}{$\begin{array}{l}\mathrm{CV} \\
\mathrm{DOE}\end{array}$} & \multirow{2}{*}{$\begin{array}{l}\text { Calorific value } \\
\text { Design of Experiments }\end{array}$} \\
\hline ASTM & American Society for Testing and Materials & & \\
\hline BD & Biodiesel & EGT & Exhaust Gas Temperature \\
\hline \multirow[t]{2}{*}{ BD20 } & Biodiesel blend of $80 \%$ Fossil diesel and & EN & European Committee for Standardization \\
\hline & $20 \%$ biodiesel & GHG & Green House Gas \\
\hline \multirow[t]{2}{*}{ BD30 } & Biodiesel blend of $70 \%$ Fossil diesel and & GC-MS & Gas Chromatog129raphy Mass \\
\hline & $30 \%$ biodiesel & & Spectrometry \\
\hline \multirow[t]{2}{*}{ BD50 } & Biodiesel blend of $50 \%$ Fossil diesel and & $\mathrm{S} / \mathrm{N}$ & Signal to Noise Ratio \\
\hline & $50 \%$ biodiesel & SNR & Signal to Noise Ratio \\
\hline \multirow[t]{2}{*}{ BD80 } & Biodiesel blend of $20 \%$ Fossil diesel and & KW & Kilowatt \\
\hline & $80 \%$ biodiesel & $\mathrm{NaOH}$ & Sodium Hydroxide \\
\hline BP & Brake Power & $\mathrm{NO}_{\mathrm{X}}$ & Nitrogen oxide \\
\hline BSFC & Brake Specific Fuel Consumption & WCO20 & Waste Cooking Oil Biodiesel blend of $80 \%$ \\
\hline BTE & Brake Thermal Efficiency & & Fossil diesel and $20 \%$ biodiesel \\
\hline FD & Fossil Diesel & WCO40 & Waste Cooking Oil Biodiesel blend of60 \% Fossil \\
\hline FFA & Free fatty acid & diesel an & d $40 \%$ biodiesel \\
\hline $\mathrm{CN}$ & Cetane Number & WCO100 & 100\% Waste Cooking Oil Biodiesel fuel \\
\hline $\mathrm{CO}$ & Carbon Monoxide & WHO & World Health Organization \\
\hline $\mathrm{CO}_{2}$ & Carbon Dioxide & UBHC & Unburnt hydrocarbon \\
\hline
\end{tabular}

\section{INTRODUCTION}

There is a global transition to alternative fuels for CI engines due to the evident depletion of fossil derived energy resources coupled with harmful environmental effects arising from production and usage of these fossil-based fuels (Naylor\& Higgins, 2018). Fossil diesel (FD) fuel has enjoyed huge market share powering heavy trucks, locomotives, agricultural equipment and sea transport. FD fuel engines have been the preferred choice because they are reliable, provide good fuel economy and high efficiency (Pirouzfar et al., 2008). However, diesel engines produce hazardous emissions such as nitrogen oxides $\left(\mathrm{NO}_{\mathrm{X}}\right)$, unburnt hydrocarbons $(\mathrm{UBHC})$, carbon monoxide $(\mathrm{CO})$, carbon dioxide $\left(\mathrm{CO}_{2}\right)$, soot and sulphur and these have detrimental environmental and human health effects.Research hasshown that amongst the available alternative energy sources to mitigate greenhouse gas emissions, bioenergy is the only solution of which biofuels are the leading candidates for the transport sector(Pirouzfar et al. 2009; Pirouzfar et al. 2012). Biofuels development will lead to a 
carbon neutral environment, and will aid in development of a waste to resources circular economy and increased energy security (Ahmad et al., 2011). Biodiesel is gaining attention as a viable replacement for FD due its non-toxic, biodegradable, renewable nature, and its generation of lower emissions. This renewable fuel can be derived from a variety of feed stocks which can be vegetable oil, edible or non-edible, animal fats or algae and waste cooking oil (WCO) (Atabani et al., 2012; Kafuku\&Mbarawa, 2010; Rashid et al., 2008). Commercialization of biodiesel (BD) production will depend on its financial viability and technical advancement of the process. This is mainly dependent on feedstock selection as this constitutes $70 \%$ of the total production cost (Firestone, 1989).Despite all that,there was a $700 \%$ increase in BD production in the period 2005 to 2015 and this is expected to be $35 \%$ higher than that by 2025 (Neeft et al. 1996). Usage of edible vegetable oils for $\mathrm{BD}$ production has also faced some negativepublicitydue to the food vs fuel controversy. This has necessitated the switch to non-edible feedstocks. Nonedible feedstocks such as Karanja, Jatropha, neem, cotton seed and micro algae can be farmed on marginal lands and do not complete with food chain supplies for resources. This has also led to the introduction of WCO as a viable feedstock for BD production (Alarcón et al., 2017; López et al., 2015).According to Rodríguez et al. (2017), 15 million tons of WCO are being generated per year globally creating disposal challenges for manymunicipalities (Kalam et al., 2011). A study undertaken by the WHO revealed that every 1 liter of WCO oil disposed of is bound to contaminate 1000 liters of water (Martinez et al. 2013).In line with that a lot of WCO is illicitly being unloaded into waterways and landfills causing environmental contamination and higher energy consumption in water works (Martinez et al. 2013). Utilization of WCO to deliver BD will offer economic benefits since it will reap substantial benefits from reduction in water contamination, employment creation, improving energy security and boost in localized business growth. Usage of WCO as a BD feedstock is therefore a novel solution aimed at a tackling disposal challenges by moving towards a circular economy creating employment and reduction in GHG emissions and so make the world more habitable(Yan et al., 2014). WCO contains high free fatty acid content (FFA) due to its exposure to high temperatures of cooking (Chhetri et al., 2008). High FFA will lower the WCOto BD conversion rate and yield. It also has high water content which can cause hydrolysis issues (Carlini et al., 2014).To circumvent all these challenges the oil is first preheated and acid esterified to remove water and lower the FFA content before transesterification is initialized.

Biodiesel is extracted from various feedstock oils using the transesterification process. Transesterification is a reaction through which a triglyceride which is present in vegetable oil and animal fats reacts with an alcohol usually methanol or ethanol in the presence of a catalyst (acid, alkali or enzyme) to a form an ester and glycerol. Tyson and McCormick (2006) suggest that utilizing methanol results in less viscous methyl ester compared to ethanol. Knothe and Steidley(2005) report that methyl esters are destined to yield better engine performance in comparison to ethyl esters. Some researchers have argued that higher and more branched alcohols result in better engine performance (Huber et al., 2006). Reports of increased injector gumming and clogging has been reported with higher, more branched and expensive alcohols (Narasimharao et al., 2007). This process can be base, or acid catalyzed. The base catalyzed process is quick and consumes less alcohol. Transesterification is influenced mainly by molar ratio, type of catalyst and its concentration, reaction time and reaction temperature. The main objective of transesterification is to reduce the viscosity of the oil which has detrimental effects on engine durability. BD feedstocks differ from one country to another hence localized feedstock characterization and development is vital. It is advisable to produce the feedstock locally to make the BD supply chain cost effective. A study by Paper and Bilgin(2015) aimed at producing the lowest kinematic viscosity BD found that an optimum alcohol/oil molar ratio ranging from $6: 1$ to $15: 1$, catalyst concentration ranging from $0.5 \%$ to $1.75 \%$, reaction temperature ranging from $60{ }^{\circ} \mathrm{C}$ to $90^{\circ} \mathrm{Cwere}$ determined to be the optimal conditions. Other researchers have suggested the optimal 
approximate proportions of reactants and products of transesterification process to be $100 \mathrm{~kg}$ of oil plus $10 \mathrm{kgs}$ of methanol or ethanol equals $100 \mathrm{kgs}$ of BD plus $10 \mathrm{kgs}$ of glycerol (Datta \& Mandal, 2016). The fatty acid content is the key factor in determining the number of steps to be carried out for transesterification. The first step is acid catalyzed and is aimed at reducing the fatty acid level to within the required level to undertake the alkali process. Cooking results in conversion of vegetable oil make-up and its properties. High exposure to high temperatures leads to oxidation and hydrolysis of the oil (Datta \& Mandal, 2016) This increases the viscosity of the oil as a result of polymeric and dimeric acid formation hence the high FFA from cooking must undergo pretreatment to lower it to below $1 \mathrm{wt} \%$. This helps to inhibit the saponification process. After transesterification the BD is washed, and the byproduct glycerol separated accordingly. Parameters of transesterification have been arrived at using the trial-and-error method but few studies have tried to optimize these to suite their feedstock makeup. In order to be sure about the optimal conditions required for the WCO available in this study, the Taguchi method was utilized since it has the capability to lower costs. The parameters for transesterification are interrelated since molar ratio is also dependent on catalyst concentration and type. The concentration is also influenced by difference in molar ratio as well as feedstock make up of catalyst to be used. Optimal conditions are vital for maximum yield which will subsequently result in lowering the cost of BD production. A study by Sahoo and Das (229) extracted BD from non-edible feedstocks such as Jatropha, Polanga and Karanja. In this evaluation method influence of process was verified. It was concluded that the influential process for transesterification of BD were type of catalyst, molecular ratio of alcohol, reaction time and temperature.

Masjuki (2014) attempted to optimize the process of high FFA WCOBD production. The researcher developed a model for optimizing pretreatment with ferric chloride. The researcher managed to optimize process parameters by utilizing surface response methodology modelling. From the model result analysis, it was concluded that the optimal conditions for high FFA content were molar ratio of 7:1, reaction time of 3 hours and temperatures of $60{ }^{\circ} \mathrm{C}$. Performing $\mathrm{BD}$ under the optimal conditions resulted in a yield of $81 \%$.

Rodriquez et al. (2017) extracted BD from Polanga oil. Initial evaluation of FFA content unveiled that the oil had a high FFA composition of $59.30 \mathrm{mg}$ of $\mathrm{KOH}$. The researchers had to perform degumming esterification, and then transesterification to better the BD quality. The FFA was reduced to $0.34 \mathrm{mg}$ of $\mathrm{KOH}$ before initializing transesterification. Molar ratio of $10: 1$ methanol to oil ratio, $1 \mathrm{wt} \%$ of $\mathrm{NaOH}$ temperature of $50{ }^{\circ} \mathrm{C}$ for 2 hours were the process parameters utilized in the process. The BD produced conformed to ASTM D6571 and EN14214 standards. The BD produced was blended with FD at $10 \% \mathrm{Bd}$ to $090 \mathrm{BD}$. Performance result analysis revealed a $2.3 \%$ brake thermal efficiency increment and $3.06 \%$ reduction in brake specific fuel consumption. This was key in suggesting that the Polanga oil was aviable alternative fuel forCi engines.

Chumuang and Punsuvon(2017) produced BD from an alkali catalyzed transesterification of WCOBD process with the aid of tetrahedron as a cosolvent. Preforming a 5 level 4 factor coupled to surface response technology the researchers were able to evaluate the optimal parameters for BD production. The researchers managed to develop a prediction scheme for BD yield from given feedstock oil make up. According to this report amolar ratio of 11.6:1, 100.14 $\mathrm{min}, 2.85 \mathrm{wt} \%$ of catalyst and $8.65 \% \mathrm{v} / \mathrm{v}$ of tetrahedron were optimal values for maximum yield. A yield of $99.43 \%$ was determined under these optimal process parameters.

Chakraborty et al. (2009) performed an extraction of Termilia derived BD. Fatty acid composition, kinematic viscosity and energy content of 28.7 linoleic, 32.9 palmitic and 31.4 oleic acid and 25.5 cst. $3740 \mathrm{MJ} / \mathrm{kg}$ according to 
EN14214 Standard. Despite most of properties conforming to set standards, flash point was noted to be $90{ }^{\circ} \mathrm{C}$ which was less than required minimum value of $120^{\circ} \mathrm{C}$.

Xuan and Leung (20110 extracted BD using transesterification from camelia seed oil. Analysis of process parameters revealed that reaction time, catalyst concentration, Molar ratio of alcohol to oil and reaction temperature were influential in BD production quality. The optimal process parameters which yielded the highest yield were methanol ratio of $8: 1,70$ min reaction time, $1 \mathrm{wt} \%$ catalyst concentration and temperature of $51^{\circ} \mathrm{C}$. The BD produced conformed to ASTM D67571 AND EN14214 international norms.

The above literature survey has indicated that process conditions vary, therefore ideal parameters that suite each type of feed stock accessible locally becomes a priority. Hence this work is aimed to assess the suitability of WCO as a viable of feedstock for BD creation. The production parameters were optimized utilizing the Taguchi technique. This was done in MINITAB-16 programming that could perform experimental design and analysis of several factors. The BD created was characterized and properties evaluated in contrast to neat diesel and thereafter tested in an engine. Motor preliminaries were done to check the presentation and discharge conduct of WCO from confined feedstock. Fuel mixes of WCO20, WCO40 and WCO100 were tested and results contrasted with those of Fossil diesel. Performance parameters such as brake thermal efficiency, brake specific fuel consumption and exhaust gas temperature were measured and or evaluated. Exhaust emission parameters evaluated were $\mathrm{NO}_{x}, \mathrm{CO}, \mathrm{CO}_{2}, \mathrm{UBHC}$, and smoke opacity compared to FD.

\section{RESEARCH METHODS AND MATERIALS}

\subsection{Characterization of Waste Cooking Oil}

WCO was purchased from Enfield, a company that deals with collection of industrial and domestic used oils. The oil was heated to $100{ }^{\circ} \mathrm{C}$ to get rid of food components as well as all unwanted residues. Thereafter the WCO was prepared and evaluated for fatty acid composition by using gas chromatography coupled to a mass spectrometer (GC/MS), Shimadzu model QP 2010 GC-MS, capillary column Durabond, stationary phase DB-5HT (280 (W) X 280 (H) X175 (D). The fatty acid composition was evaluated based on ASTM standards. The results are tabulated in Table 1. The fatty acid composition evaluation was necessary to gain an understanding of the makeup of the feedstock and so help to explain the characteristics of the $\mathrm{BD}$

Prior to the transesterification process the WCO was also subjected to physicochemical property valuation in relation to ASTM D6751 standards. The properties evaluated were density, kinematic viscosity, acid value, saponification, and water content, The results are shown in Table 1. The properties were assessed in three trials which were then averaged to gain mean value and results.

Table 1: Fatty Acid Composition of the oil and Physiochemical Properties of Waste Cooking Oil 


\begin{tabular}{|l|c|c|c|}
\hline Property & C-Chain & $\begin{array}{c}\text { Measured } \\
\text { WC Oil } \\
\text { property }\end{array}$ & $\begin{array}{c}\text { Waste cooking } \\
\text { oil as reported } \\
\text { by [32] }\end{array}$ \\
\hline Myristic & $\mathrm{C} 14: 0$ & 0.11 & 0.41 \\
\hline Palmitic & $\mathrm{C} 16: 0$ & 5.06 & 8.22 \\
\hline Palmitoleic & $\mathrm{C} 16: 1$ & 0.44 & 0.89 \\
\hline Stearic & $\mathrm{C} 18: 0$ & 8.22 & 5.61 \\
\hline Oleic & $\mathrm{C} 18: 1$ & 54.22 & 48.83 \\
\hline Linoleic & $\mathrm{C} 18: 2$ & 19.88 & 10.94 \\
\hline Linolenic & $\mathrm{C} 18: 3$ & 5.72 & 2.68 \\
\hline Arachidic & $\mathrm{C} 20: 0$ & 0.61 & 0.56 \\
\hline Eicosenoic & $\mathrm{C} 20: 1$ & 1.31 & 0.97 \\
\hline Lignoceric & $\mathrm{C} 24: 0$ & 0.08 & \\
\hline Others & & 4.36 & 20.89 \\
\hline Density (kg/m3) & & 922 & \\
\hline Acid Value (mg of $\mathrm{KOH})$ & & 8.67 & \\
\hline kinematic Viscosity (cst) & & 34.67 & \\
\hline Iodine Value g D/100g & & 88 & \\
\hline Saponification value $\mathrm{mg}$ of $\mathrm{KOH}$ & & 212.1 & \\
\hline
\end{tabular}

\section{FFA Evaluation and Pretreatment Waste Cooking Oil}

High FFA of above $2 \%$ require a two-step production process. Titration method was utilized to evaluate the acid value of the oil so as guide the researcher to perform single or two step transesterification process. The material used in titration method were $0.1 \%$ of $\mathrm{KOH}$ solution, phenolphthalein, and isopropyl alcoholsulphuric acid $\left(\mathrm{H}_{2} \mathrm{SO}_{4}\right)$, the process was performed according to ASTM D974 standard. all the chemicals were obtained from Sigma Aldrich (South Africa). Phenolphthalein is hereby utilized to locate the reaction end point. A small beaker is used to make clear water by mixing it with isopropyl alcohol then small drops of are added until the mixture reaches endpoint by staying at constant pink color for about 12 seconds.

The oil was evaluated Acid Number of the oil was calculated using the following Eq.1 below.

Acid Value $=\frac{56.1 \times 0.1 \mathrm{~N} 15.46 \mathrm{~mL}}{10 \mathrm{~g}} \mathrm{Eq}$

Where: 56.1 wasthe molecular weight of $\mathrm{KOH}$ used in the titration $(\mathrm{g} / \mathrm{mol}), 15.46$ was volume of $\mathrm{KOH}$ consumed during titration $(\mathrm{ml}) .0 .1 \mathrm{~N}$ standard solution represents the concentration of $\mathrm{KOH}$ used in the titration, and $10 \mathrm{~g}$ was the mass of oil sample used in the analysis.

The acid number was $8.67 \mathrm{mg}$ of $\mathrm{KOH}$ which corresponds to $4.33 \%$ FFA (Chhetri 2008). The acid was evaluated by the following formula, $\frac{\text { Acid Value }}{2}$ and was found to be higher than $1 \%$ FFA so warranted alkali transesterification hence pretreatment was performed to reduce FFA \%. WCO was placed in a flask which was put on hot plate maintained at $60{ }^{\circ} \mathrm{C}$. Methanol molar ratio (9:1) and $\mathrm{H}_{2} \mathrm{SO}_{4}$ at $1 \mathrm{wt} \%$ were separately mixed in a beaker and stirred for 4 minutes. The methanol acid mixture was then added to the flask (1 liter) containing WCO. The flask contents were then left for 75 minutes before transesterification was begun.

\section{Transesterification}

The product of the esterification process was FFA evaluated using titration to confirm the content percentage and was found to be $0.688 \mathrm{mg}$ of $\mathrm{KOH}$. This was in the within the range required to initialize transesterification. The process 
was performed at molar ratio 6:1, $1 \mathrm{wt} \%$ at $65^{\circ} \mathrm{C}$ for 65 minutes and yield was calculated using Eq. 2 below. And the process is depicted in Figure 1 below.

Yield $\%=\frac{\text { Mass ester }}{\text { Mass } \text { Oil }} \% \mathrm{Eq}$

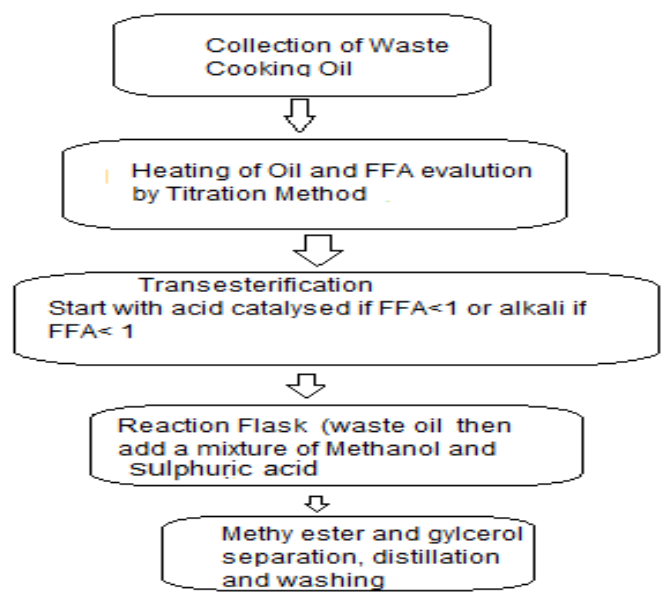

Figure 1: Biodiesel Production Process

Figures 2 and Figure 3 show the stages that the WCO underwent before biodiesel was formed.

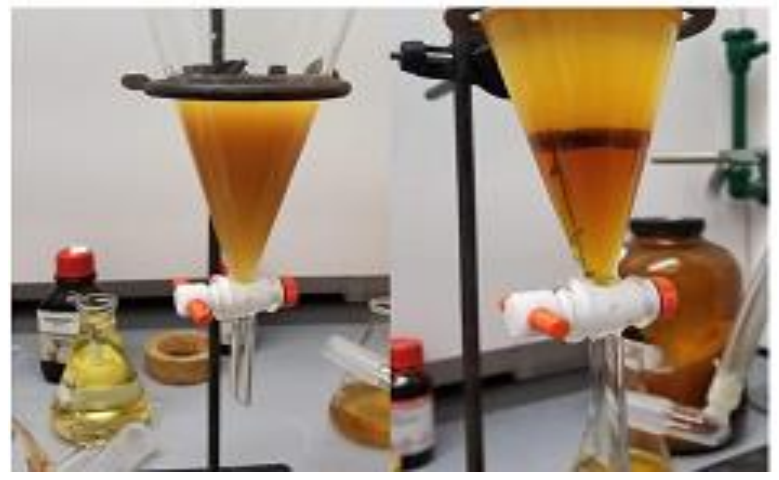

Figure 2: Biodiesel Production Process Initial Stages

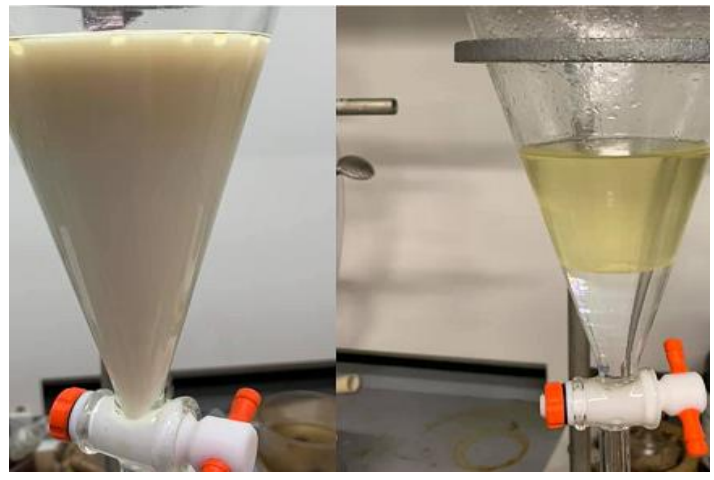

Figure 3: Biodiesel Production Process: Final Stages

\subsection{Waste Cooking Biodiesel Process Parameter Optimisation}

Most system processes rely upon some controllable variables and in line with that, the BD production process depends on alcohol to oil (molar ratio), type and concentration of catalyst, reaction temperature and reaction time. To understand the impact of these control factors on production of BD several trials must be performed. The number of these can be reduced by utilising the Taguchi design of experimental methods since it is capable of generating reliable data sets for analysis. Design of Experiments (DOE) offer efficient examination of the control factors that impact the reactions. Taguchi analysis was developed by a Japanese quality administrator Dr Genichi Taguchi. This tool is utilised for optimising manufacturing processes. Each exploratory condition is called a "Run" and the reaction estimation a perception. The whole arrangement of runs is the "Design". To limit time and cost, we can utilize plans that prohibit a portion of the factor level mixes. Factorial plans in which at least one level mixes are rejected are called partial factorial plans. These are valuable in factor screening since they diminish the quantity of trials to a reasonable size. The base number of examinations required is given by the Eq.3 
$\mathrm{N}=[(\mathrm{L}-1) * \mathrm{P}]+1 \quad \mathrm{Eq}$

Where $\mathrm{N}=$ least number of tests, $\mathrm{L}=$ number of levels, $\mathrm{P}=$ number of variables

Basic strategies in DOE are done by trial and error but the Taguchi method is a statistical design approach used to lower experimental attempts thereby reducing the cost and duration of the evaluation process. The chart Figure 4 shows the design flow chart for the Taguchi method. In this method a variable denoted signal to noise ratio (S/N) is used to denote the influence of noise contribution on performance. The higher the $\mathrm{S} / \mathrm{N}$ ratio the better the quality of yield value(Gadhave\&Ragit, 2020).

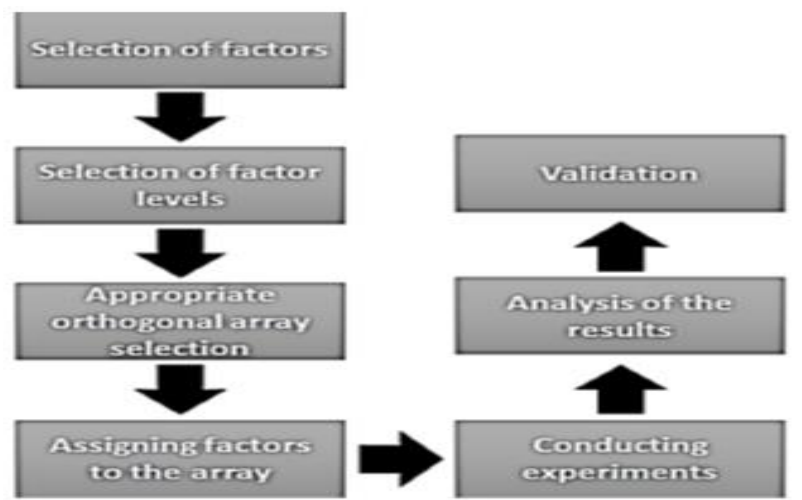

Figure 4: Taguchi Process Parameter Optimisation Method

$\mathrm{S} / \mathrm{N}$ measures the variety of reaction comparative with ostensible or target esteem. $\mathrm{S} / \mathrm{R}$ is the estimation used to portray what amount of wanted sound is available in a sound chronicle, rather than undesirable sound (noise). Two kinds of S/Nutilized in the current work were: 'smaller the better', and 'bigger the better'. At the point when the reaction is to be boosted, 'smaller the better'S/R was suitable and was registered utilizing Eq.4, while 'bigger the better' SNR was wellsuited for the limiting reaction, applying Eq. 5. 'Bigger the better' was selected and used for optimisation process parameters in this research.

The Signal to Noise ratios (S/N) (Gadhave\&Ragit, 2020):

For system responses Smaller the better:

$\mathrm{S} / \mathrm{N}=-10 \log 10$ [mean of sum of squares of measured data] Eq (4)

This type of $\mathrm{S} / \mathrm{N}$ ratio is chosen for undesirable system outputs like emissions, fuel consumption, etc. whose ideal value is zero.

For system responses bigger the better:

$\mathrm{S} / \mathrm{N}=-10 \log 10$ [mean of sum squares of reciprocal of measured data] Eq (5)

\subsection{Selection of Process Parameters}

Factors that were selected for this optimisation process were methanol oil ratio (molar ratio), KOH catalyst concentration, reaction time and reaction temperature as these have influence on yield of BD produced. In the Taguchi method a performance test was undertaken by varying all the factors simultaneously and this minimised the number of tests to be performed. The variation in the selected factors are shown in orthogonal array L9 shown in Table 2. 
Table 2: Orthogonal Array L9 for the Assigned Factors and Their Levels

\begin{tabular}{|c|c|c|c|c|c|c|}
\hline Run no. & Molar Ratio & $\begin{array}{c}\text { Concentration } \\
(w+\%)\end{array}$ & $\begin{array}{c}\text { Reaction Time } \\
(\text { min) }\end{array}$ & $\begin{array}{c}\text { Reaction } \\
\text { temperature } \\
(o C)\end{array}$ & $\begin{array}{c}\text { Average } \\
\text { Yield } \%)\end{array}$ & S/Nratio \\
\hline 1 & $6: 1$ & 0.5 & 60 & 65 & 88.93 & 38.98 \\
\hline 2 & $6: 1$ & 1.0 & 70 & 75 & 91.21 & 39.2 \\
\hline 3 & $6: 1$ & 1.5 & 80 & 85 & 88.64 & 38.65 \\
\hline 4 & $7: 1$ & 1.0 & 70 & 85 & 85.62 & 39.43 \\
\hline 5 & $7: 1$ & 1.5 & 80 & 65 & 93.63 & 39.29 \\
\hline 6 & $7: 1$ & 0.5 & 60 & 75 & 92.12 & 38.81 \\
\hline 7 & $8: 1$ & 1.5 & 80 & 75 & 87.22 & 38.95 \\
\hline 8 & $8: 1$ & 0.5 & 60 & 85 & 88.59 & 39.38 \\
\hline 9 & $8: 1$ & 1.0 & 70 & 65 & 93.14 & 39.07 \\
\hline
\end{tabular}

\section{Engine Test Arrangement}

The experimental set up included a single cylinder water cooled direct Kirloskar engine operated at constant speed of 1500 $\mathrm{rpm}$. The engine was coupled to an eddy current dynamometer that was utilized for engine loading purposes. Engine details are shown In Table 3 below. The set comprised all essential instruments for injection pressure and angle evaluation. All these were linked to a PC for analysis. Instrumentation was also provided for measuring air flow, temperature and fuel flow rate. The whole system set is illustrated in Figure 6. Injection pressure and angle crank instruments were linked to data acquisition for analysis. The load cell was used to load, monitor and control the progress of the tests. Volumetric fuel utilization and gas fumes emanation, for example, $\mathrm{CO}, \mathrm{HC}$, and $\mathrm{NO}_{\mathrm{x}}$ were estimated. From the underlying estimation, brake thermal efficiency (BTE), brake explicit fuel consumption (BSFC), brake power (BP) for various mixes and distinctive injection pressure were determined and recorded. An AVL 444 di-gas analyzer was utilized for gas measurements for NOx, UBHC, $\mathrm{CO}_{2}$ and $\mathrm{CO}$ and an $\mathrm{AVL} 437 \mathrm{C}$ smoke meter was used for smoke opacity measurement. The engine was initially fueled by FD fuel during warm up for about 15 minutes. The results of the analyzed gas emission measured against load setting are discussed under the Results and Discussion section.

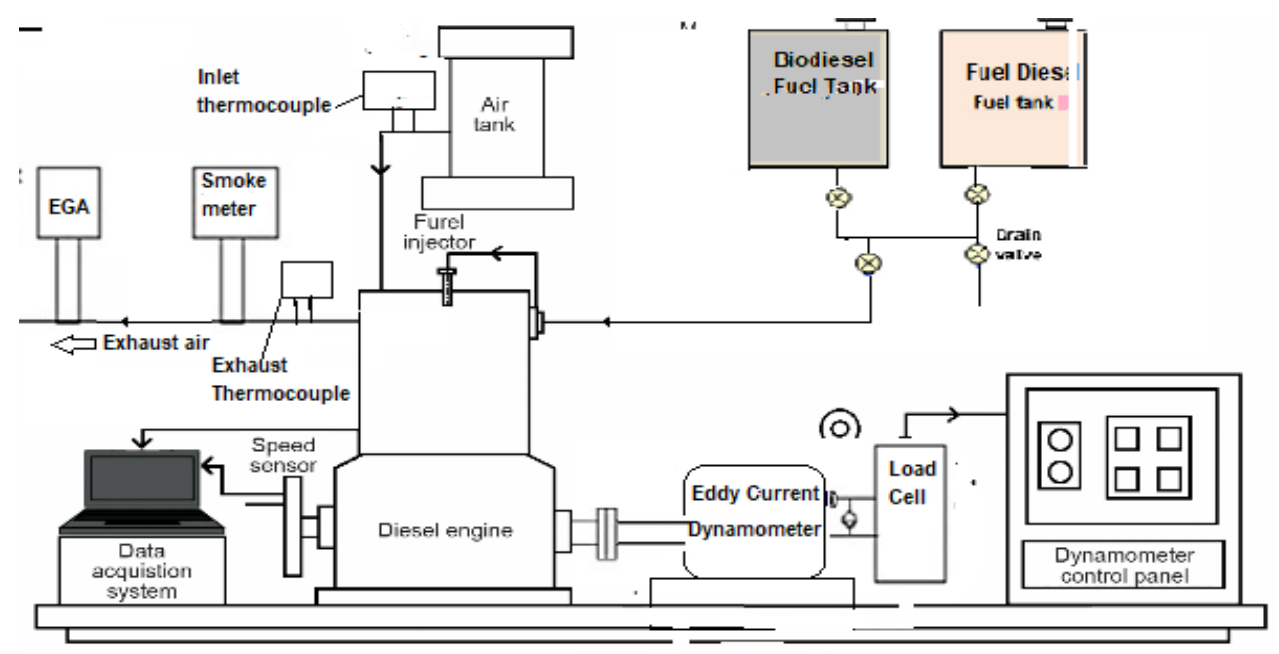

Figure 6: Engine Test Configuration

Table 3: Engine Specifications used in the Experiment 


\begin{tabular}{l|l}
\hline Parameter & Position value \\
\hline \hline Engine Mode1 & Kirloskar \\
Type & Two cylinder, horizontal 4-stroke, \\
Cooling Medium & Water cooled \\
Revolutions per & $1300 \mathrm{rpm}$ (constant) \\
Minute & $4.4 \mathrm{~kW}(7 \mathrm{Hp})$ \\
Rated Brake Pover & $87.5 \mathrm{~mm}$ \\
Cylinder Bore & $110 \mathrm{~mm}$ \\
Piston Stroke & 17.5 (variable) \\
Compression Ratio & $23^{\circ} \mathrm{BTDC}$ \\
Injection Timing & 220 bars \\
Injection pressure & Eddy Current Dynamometer \\
Loading system &
\end{tabular}

Table 4: Uncertainties Estimations of Measured and Calculated Parameters

\begin{tabular}{|c|c|c|c|c|}
\hline Quantity & & Range & Accuracy & Uncertainty \\
\hline \multirow[t]{4}{*}{ AVL gas analyzer } & $\mathrm{NO}_{x}$ & $0-5000 \mathrm{ppm}$ & $\pm 10 \mathrm{ppm}$ & \pm 0.2 \\
\hline & $\mathrm{HC}$ & $0-20000 \mathrm{ppm}$ & $\pm 1 \mathrm{ppm}$ & \pm 0.3 \\
\hline & $\mathrm{co}$ & $0-10$ vol $\%$ & $\pm 0.01 \%$ & \pm 0.22 \\
\hline & $\mathrm{CO}_{2}$ & $0-20$ vol $\%$ & $\pm 0.03 \%$ & \pm 0.21 \\
\hline AVL smoke meter & & $0 \%-100 \%$ & $\pm 0.2 \%$ & \pm 0.22 \\
\hline Thermocouple & & $0-1000^{\circ} \mathrm{C}$ & $\pm 1{ }^{\circ} \mathrm{C}$ & \pm 0.15 \\
\hline Dynamometer & & $0-250 \mathrm{~V}, 0-25 \mathrm{~A}$ & $\pm 1 \mathrm{~V}, \pm 0.5 \mathrm{~A}$ & $\pm .05, \pm 0.1$ \\
\hline In-cylinder pressure & & $0-220$ bars & $\pm 0.2 \mathrm{bar}$ & \pm 0.1 \\
\hline $\begin{array}{c}\text { Crank Anlge } \\
\text { encorder }\end{array}$ & & & \pm 1 & \pm 0.25 \\
\hline $\begin{array}{l}\text { Exhasut gas } \\
\text { temprature }\end{array}$ & & & $\pm 2{ }^{\circ} \mathrm{C}$ & \pm 0.1 \\
\hline Brake Power & & & & \pm 0.75 \\
\hline $\begin{array}{l}\text { Brake specific fuel } \\
\text { consumption }\end{array}$ & & & & \pm 0.80 \\
\hline
\end{tabular}

The error of the experimental procedure was evaluated as follows and the overall uncertainty was $1.26 \%$. The uncertainties of measured and calculated parameters are shown in Table 4.

Overall uncertainty $=$ $\sqrt{\text { uncertainity of }(N)^{2}+(B T E)^{2}+(B S F C)^{2}+(C O 2)^{2}+(C O)^{2}+(N O X)^{2}+(U B H C)^{2}+(E G T)^{2}+(\text { smoke })^{2}}$

\section{RESULTS AND DISCUSSION}

Table 5 shows the average yield and $\mathrm{S} / \mathrm{N}$ values determined by the experiments that were performed for nine sets of arrangements as detailed in the orthogonal array in Table 2 above. Average yield assessed by the evaluation was 89.91 with the maximum yield being from run number 5 which was based on molar ratio of $7: 1,1.5 \mathrm{wt} \%, 80$ minutes and $65^{\circ} \mathrm{C}$. The mean $\mathrm{S} / \mathrm{N}$ value was 39.07 with the highest $\mathrm{S} / \mathrm{N}$ yield being shown by run number 8 . The $\mathrm{S} / \mathrm{N}$ distribution for set of experiments is shown in Figure 7 below.

Table 5: Average Yield and S/N Ratios Resulting from the Experiments 


\begin{tabular}{|c|c|c|c|c|c|}
\hline Run no. & Sample 1 & Sample 2 & Sample 3 & Av Yield & S/N ratio \\
\hline 1 & 88.78 & 88.90 & 88.93 & 88.93 & 38.98 \\
\hline 2 & 91.28 & 90.88 & 9.21 & 91.21 & 39.2 \\
\hline 3 & 88.87 & 88.58 & 88.64 & 88.64 & 38.95 \\
\hline 4 & 84.21 & 84.52 & 85.62 & 85.62 & 39.65 \\
\hline 5 & 95.10 & 93.00 & 93.63 & 93.63 & 39.43 \\
\hline 6 & 92.16 & 92.04 & 92.19 & 92.12 & 38.29 \\
\hline 7 & 87.10 & 87.24 & 87.22 & 87.22 & 38.81 \\
\hline 8 & 88.36 & 88.56 & 88.59 & 88.59 & 39.95 \\
\hline & 93.12 & 93.28 & 93.14 & 93.14 & 39.38 \\
\hline & Average & & & $\mathbf{8 9 . 9 1}$ & $\mathbf{3 9 . 0 7}$ \\
\hline
\end{tabular}

Table 5 portrays the $\mathrm{S} / \mathrm{N}$ proportions and the association between the yield and the $\mathrm{S} / \mathrm{N}$ in relation to WCOBDas seen in the various example results. The variation of $\mathrm{S} / \mathrm{N}$ values for the four factors are summarized in Table 6 . The impact of every preliminary factor was settled from the greatest qualification in the characteristics between the mean $\mathrm{S} / \mathrm{N}$ extents at every level. To play out an examination of the relative essentials of each limit, an examination of contrast (ANOVA) was conducted based on the results obtained to improve utilization of the Taguchi strategy and make it more productive. This provided in formation on the general effects of limits and their correspondences concerning the different results. Considering the ANOVA results, the fundamental factor in the formation of biodiesel were reaction temperature e, followed by catalysts concentration, molar ratio and reaction time. The variations for the four variables are summarized in Table 6. The commitments of each trial factor were resolved from the maximum distinction in the qualities between the mean $\mathrm{S} / \mathrm{N}$ proportions at each progression. To play out an investigation of the family member significance of every boundary, an investigation of difference (ANOVA) was utilized for the outcomes acquired to utilize the Taguchi technique more efficiently. This provided data on the overall impacts of boundaries and their communications concerning the various outcomes. Considering the ANOVA results, the main factor in the creation of biodiesel was reaction temperature followed by catalyst concentration which showed the highest contribution.

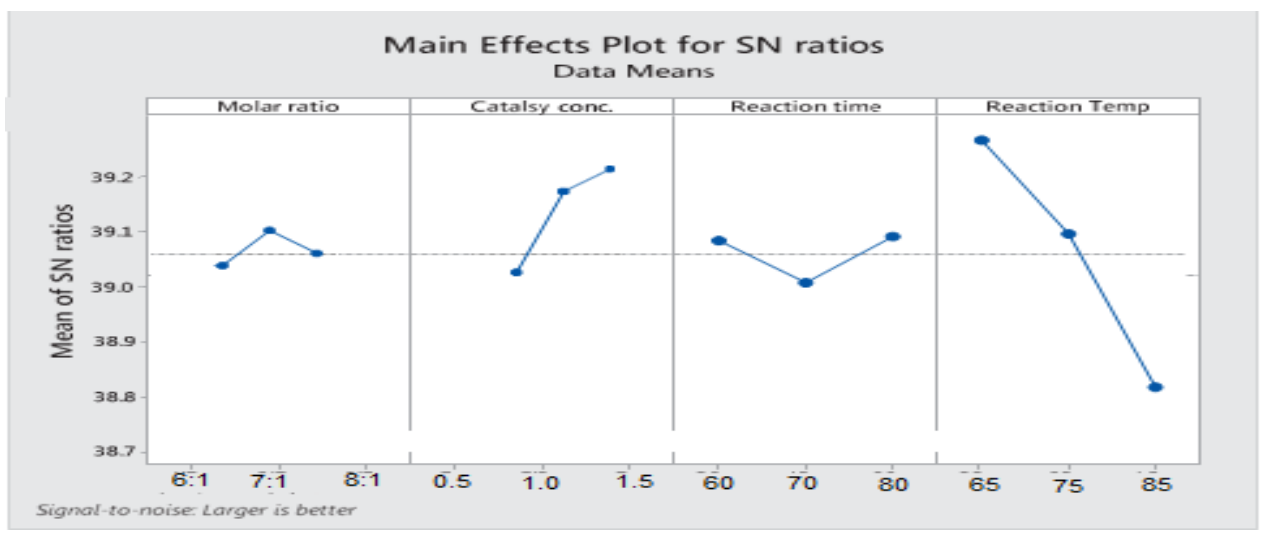

Figure 7: Mean S/N Ratio, Variation and Distribution

Table 6: Mean S/N Ratios and their Distribution 


\begin{tabular}{|c|c|c|c|c|c|c|}
\hline \multirow[t]{2}{*}{ Factors } & \multicolumn{3}{|c|}{ Level } & \multicolumn{3}{|c|}{ Variations } \\
\hline & 1 & 2 & 3 & $\mathrm{~L} 2-1$ & L3-1 & L3-1 \\
\hline A. Molar ratio (methanol/oil) & 39.04 & 39.12 & 39.07 & 0.08 & 0.03 & -0.05 \\
\hline B. Catalyst concentration (wt $\%$ ) & 39.03 & 39.17 & 39.22 & 0.14 & 0.393 & 0.05 \\
\hline C. Reaction time (min) & 39.08 & 38.88 & 39.14 & -0.2 & 0.001 & 0.26 \\
\hline D. Reaction temperature ("C) & 39.25 & 39.09 & 38.81 & -0.16 & 0.44 & -0.28 \\
\hline
\end{tabular}

Table 7: Optimum Conditions for Settling the Control Parameters and their Contributions

\begin{tabular}{|l|c|c|c|}
\hline \multicolumn{1}{|c|}{ Factors } & Level & Level description & Contribution \\
\hline A. Molar ratio (methanol/oil) & 2 & $7: 01$ & 0.054 \\
\hline B. Catalyst concentration wt $\%$ & 3 & 1.5 & 0.393 \\
\hline C. Reaction time (min) & 3 & $80 \mathrm{~min}$ & 0.001 \\
\hline D. Reaction temperature $\left({ }^{\circ} \mathrm{C}\right)$ & 1 & $65^{\circ} \mathrm{C}$ & 0.44 \\
\hline
\end{tabular}

It can be noted that based on the $\mathrm{S} / \mathrm{N}$ ratio from Table 6 , the optimal parameters were molar ratio of 7:1, catalyst concentration of $1.5 \%$, reaction time of 80 minutes, and reaction temperature of $65^{\circ} \mathrm{C}$. These are shown in Table 6 along with their contribution to yield value. It is vital to be able to evaluate optimal conditions that best suit the feed stock make up. Molar ratio is an important variable which impacts the yield of BD produced. Very low yield promotes backward reaction in which the BD produced will react with the glycerol to form an alcohol plus oil. This will result in low yields and high production costs. Increasing the molar ratio increases the BD yield to an optimal value thereafter if begins to decrease. Catalyst concentration shares the same variation as molar ratio, i.e., increasing concentrations increase yield up to peak value thereafter decrease in yield occurs. This is because a higher concentration of catalyst will enhance creation of several active sites for reaction to occur. However, recovery of the BD becomes more difficult when excessive concentrations of catalysts are used. Furthermore, from a financial point of view, higher concentrations of catalyst are not feasible since the cost of catalysts is high. Therefore, the proportion of oil to alcohol ratio is key in deciding the catalyst concentration required (Jagadale\&Jugulkar, 2012; Kansedo, 2009). Reaction temperature is also key as higher temperatures speed up the rate of fuel conversion. Optimal temperatures must be determined since excessive temperatures will render the reactants inactive. Reaction time has influence on the production of BD as well in that if the process continues beyond the optimal peak period backward reaction is likely to initialize as well. Increasing reaction time will increase yield but this is up to peak value. Most researchers have proposed that maximum BD yields are determined at durations $<1$ hour 0 minutes. Prolonged duration will reverse the reaction resulting in lower yields and acceleration of the saponification process (Mathiyazhagan\& Ganapathi, 2011).

Table 8: ANOVA of Yield Values

\begin{tabular}{ccccrc}
\hline Symbol & Source & $\begin{array}{c}\text { df(Degree of } \\
\text { Freedom) }\end{array}$ & $\begin{array}{c}\text { Adj. SS (adjusted sum of } \\
\text { squares) }\end{array}$ & $\begin{array}{c}\text { Adj. MS (adjusted mean } \\
\text { squares) }\end{array}$ & $\begin{array}{c}\text { F- } \\
\text { value }\end{array}$ \\
value
\end{tabular}


Table 8 shows the ANOVA of yield values based on impact of the parameters which were selected for study. As shown in the Table 7, if the p-estimation of a variable is more prominent than 0.05 , it shows that the impact of that variable is practically negligible. Moreover, high F-values are demonstrative of high effect. Catalyst concentration and reaction temperature showed the lowest P-values of 0.041 and 0.068 respectively. Reaction time and molar ratio revealed the highest p-value of 0.883 and 0.435 respectively meaning their impact on the reaction were low in the evaluation process. The most prominent factors therefore were reaction temperature, catalyst concentration, molar ratio and then lastly reaction time. Reaction temperature also showed the highest F-value of 13.66 and catalyst concentration of 13.14 signifying their highest impact on the determined results. Contribution from catalyst concentration, reaction temperature, molar ratio, and reaction time were $44 \%, 39.3 \%, 5.4 \%$ and $0.1 \%$ respectively as shown in Table 7 . Application of optimal conditions improved yield percentage from a maximum of $93.63 \%$ to $96.8 \%$

\section{Fuel Properties}

Characterization of fuel samples was performed and is tabulated in Table 8. The fuels were tested according to ASTM D6751 methods in the laboratory at the University of KwaZulu-Natal. The tested parameters were kinematic viscosity, density, calorific value, flash point and cetane number. The kinematic viscosity of WCO100 was 4.12 centistokes which was about $70 \%$ higher than that of FD. The kinematic viscosity of FDfuel increased with the addition of WCOBD to the blend. Flash point was noted to increase with the addition of WCOBDto the blend for all FDfuels.

Table 9: Waste Cooking Oil Biodiesel Properties and Instruments Used for Measurement

\begin{tabular}{|c|c|c|c|c|c|}
\hline Fuel blend & $\begin{array}{l}\text { Kinematics } \\
\text { viscosity, } \\
\mathrm{m}\left(\mathrm{mm}^{2} / \mathrm{s}\right)\end{array}$ & $\begin{array}{c}\text { Heating value, } \\
\mathrm{HV} \\
(\mathrm{KJ} / \mathrm{kg})\end{array}$ & $\begin{array}{c}\text { Flash point, FP } \\
\left({ }^{\circ} \mathrm{C}\right)\end{array}$ & $\begin{array}{c}\text { Density, } \\
\left(\mathrm{g} / \mathrm{m}^{5}\right)\end{array}$ & Cetane number \\
\hline Fossil Diesel & 2.42 & 44,250 & 65 & 0.836 & 49.00 \\
\hline WCO20 & 3.48 & 40,800 & 93 & 0.851 & 52.64 \\
\hline WCO40 & 3.64 & 37920 & 98 & 0.854 & 54.12 \\
\hline WCO100 & 4.12 & 34.800 & 130 & 0.900 & 56.80 \\
\hline $\begin{array}{l}\text { Measurement and } \\
\text { apparatus } \\
\text { standard test method }\end{array}$ & $\begin{array}{l}\text { Redwood } \\
\text { viscometer } \\
\text { ASTM D445 }\end{array}$ & $\begin{array}{c}\text { Bomb calorimeter } \\
\text { ASTMD240 }\end{array}$ & $\begin{array}{l}\text { Penksy } \\
\text { martens } \\
\text { ASTMD93 }\end{array}$ & $\begin{array}{l}\text { Hydrometer } \\
\text { ASTM } \\
\text { D1298 }\end{array}$ & $\begin{array}{c}\text { Ignition quality } \\
\text { tester } \\
\text { ASTMD613 }\end{array}$ \\
\hline
\end{tabular}

\section{Performance Characteristics}

\section{Brake Thermal Efficiency}

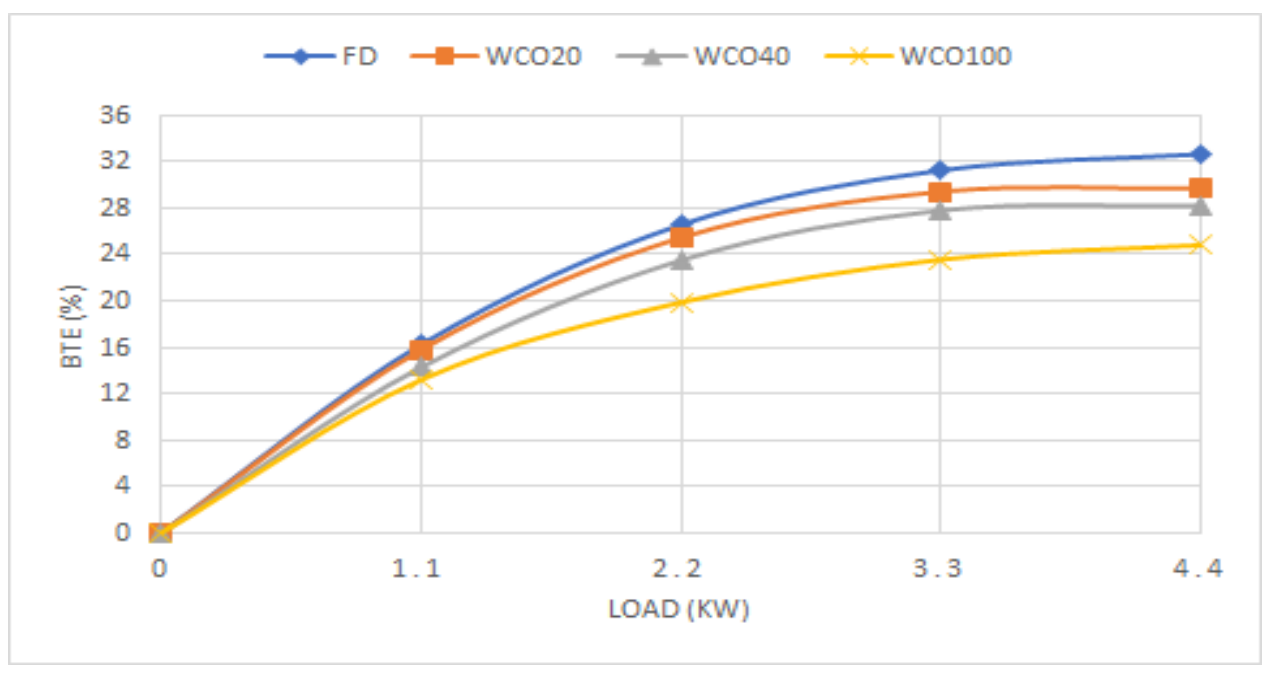

Figure 10: BTE vs Load 
Brake thermal efficiency(BTE) showed increased variation with loading for all fuels. According to (Yadav et al., 2016) BTE is the ratio of actual engine work in relation to the energy supplied by fuel. It is calculated by dividing the engine brake power by energy derived from the fuel. This parameter is used to measure engine ability to convert stored chemical energy to mechanical energy. As shown in Figure 10, maximum BTE for FD, WCO20, WCO40 and WCO100 were $32.64 \%, 29.68 \%, 28.2 \%$ and $25.8 \%$ respectively. Mean BTE for FD, WCO20, WCO40 and WCO100 were 21.34 $\%, 20.07 \%, 18.76 \%$ and $17.17 \%$ respectively. These results showed a maximum reduction in BTE of $26.51 \%$ with WCO100 compared to FD at full load. Results also revealed that the BTE decreased with increased in WCOBD content in the blends. The reduction in BTE with WCO and its blends can be attributed to lower calorific value (CV), high kinematic viscosity and density of WCO and its blends compared to FD. CV denotes the energy content of the fuel hence the lower CV of WCO and its blends which showed lower energy capability compared to FD. This is a similar trend to those found by other researchers (Ashok et al. 2017; Khalife et al., 2017; Raju et al., 2018). The reduction is mostly attributed to an increase in BD content in the blends. A study performed by Carraretto et al. (2004)showed a reduction in brake thermal efficiency and brake power with BD20, BD30, BD50 and BD80. Murillo et al. (2007)found the same trend in decreasing brake power with increasing BD content in the blend. Utlu and Koçak(2008)concluded from their study results that WFMOE showed a reduction of $4.5 \%$ in BTE which they attributed to higher kinematic viscosity and CV of the blends. Most researchers reports that a reduction in BTE can be traced to heat value which decreases with increase in BD content in the blend and kinematic viscosity which increases with blending. Kinematic viscosity will impact kinematic viscosity which will promote poor atomization of fuel and this subsequently results in larger particle generation and poor combustion profile. All this will point towards a lower energy BTE with WCO and its blends compared to FD. However, this result is opposite to what was reported by Song and Zhang (2008)who found higher power with an increase in BD content in the blends. Song and Zhang (2008) argued that this was caused by the fact that fuels are delivered on a volumetric basis in the engine. Since the BD has higher density it is able to supply more fuel hence more power output and this is able to compensate for the lower $\mathrm{CV}$ of BD blends. The other explanation is based on higher $\mathrm{O}_{2}$ content which the authors say helps to adjust injection timing and shorted ignition delay improving the combustion profile of the BD and its blends. This still needs to be substantiated as it is an unbelievable result with BD.

\section{Brake Specific Fuel Consumption (BSFC)}

Variation of BSFC with loading is shown in Figure 11. It is evident that BSCFC was decreased with loading. WCO100 had higher trends compared to FD and this decreased with an increase in blending. The results are similar to those found by many researchers (Murillo et al. 2007;Song \&Zhang 2008;Utlu\&Koçak, 2008). The CVof BD is lower than that of FD hence to compensate for lower heat values BD must consume more for same $1 \mathrm{kwH}$. Surprisingly, the CV of WCO100 was $29 \%$ lower that of FD. These results are closer to what was found by Armas et al. (2010), that BD was $12.9 \%$ lower and BSFC also showed an increment of 12 compared to FD. Haşimoğluet al. (2008)found similar trends of BSFC vs FD in which CV of BD was $13.8 \%$ lower and showed $13 \%$ higher BSFC in comparison to FD. Lin et al. (2009)found similar results with VOME showing BSFC in the range $9 \%$ to $15 \%$ with blends lower than FD in the range $12 \%$ to $16 \%$. The underlining factors influencing higher fuel consumption with BD and its blends is lower heat values of which the engine must consume more to compensate for the lower $\mathrm{CV}$. Others have suggested that higher density will compensate for lower CV and reduce the consumption significantly. Lujánet al. (2009) argued that a difference in CV of $19 \%$ resulted in almost $13 \%$ increase in BSFC due to higher density compensating for lower CV. 


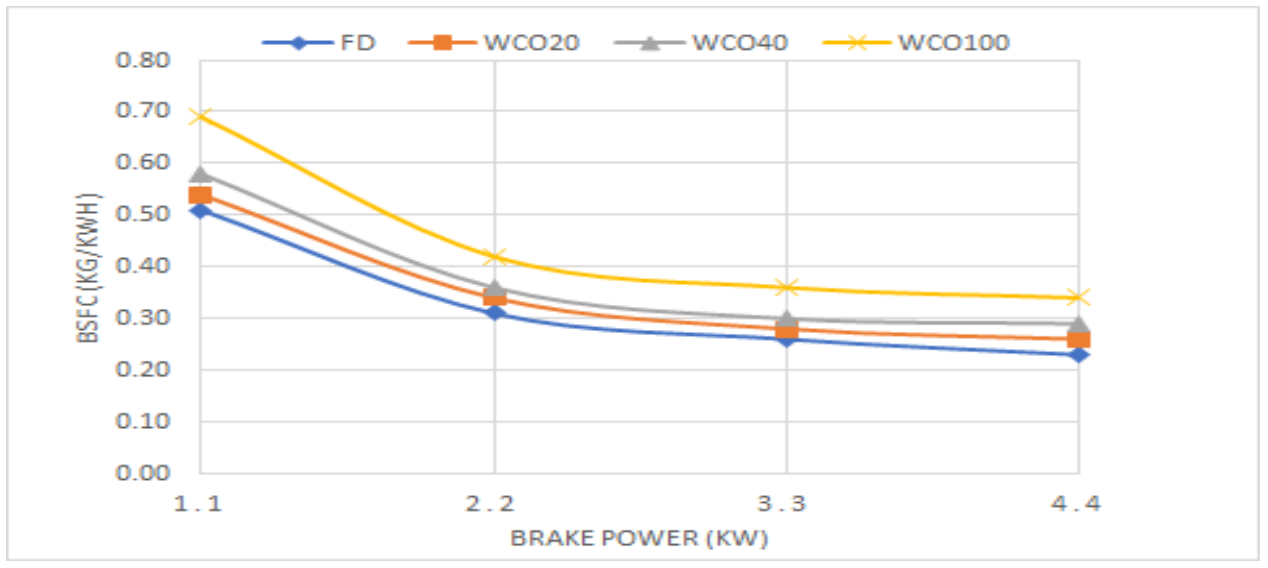

Figure 11: BSFC vs Load

\section{Exhaust gas Temperature}

Figure 12 depicts the variation of EGT with load. It can be noted that EGT increased with load for the fuels that were utilized in this investigation. The highest EGT for FD, WCO20, WCO40 and WCO100 were $640.680,720$, and $740^{\circ} \mathrm{C}$ respectively. The analysis of these trends revealed that FD showed lower trends in comparison to WCO blends. WCO100 showed the highest trend. According to Usta et al. (2005) the highest trends for WCO blends are influenced by longer ignition delays and decreased burning rate compared to FD. This prolongs the combustion process resulting in higher EGT being reached. Muralidharan and Vasudeven (2011)argue that the rise is caused by the high CN numbers of WCO blends compared to FD. High $\mathrm{CN}$ and kinematic viscosity are said to cause poor atomization which results in unburnt fuel particles available in the premix phase. This will cause higher temperatures. Analysis of WCO20 and WCO40 and WCO100 showed that the increase in WCO BDin the blends also showed an increase in EGT.

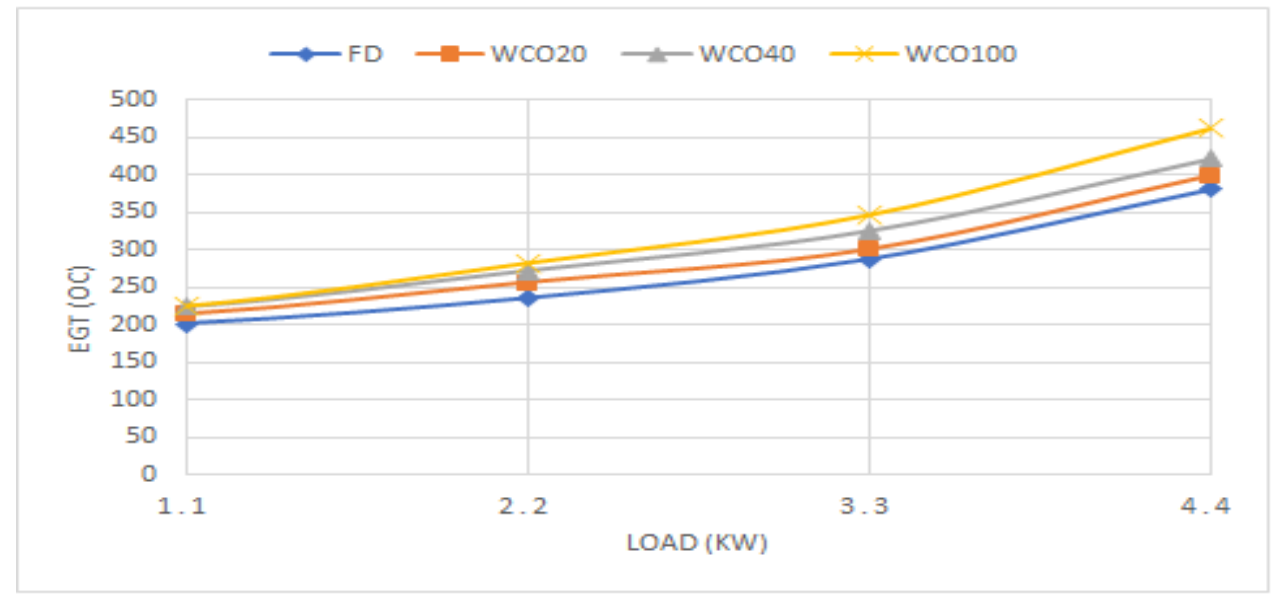

Figure 12: EGT vs Load

\section{Emission Parameters}

\section{Nitrogen oxides (NOx)}

The variations of NOX emission against load are shown in Figure 12. The highest NOx was obtained with WCO100 at full load. $\mathrm{NO}_{\mathrm{X}}$ is generated at high temperatures. $\mathrm{WCO}$ and its blends showed higher $\mathrm{NO}_{\mathrm{X}}$ with load in comparison to FD. BD usually produce higher flame temperatures compared to FD and this will influence formation of higher $\mathrm{NO}_{\mathrm{X}}$ emissions compared to FD. $\mathrm{NO}_{\mathrm{X}}$ is generated at higher temperatures with high $\mathrm{O}_{2}$ concentration and this the case with most BDfuels 
(Hansen et al., 2006; Ozsezen et al., 2009). These results agreed with those of Ozsezen et al. (2009)in which $\mathrm{NO}_{\mathrm{X}}$ emissions were increased by $22.3 \%$ compared to FD fuel. Dorado et al. (2003)also found an increase of $20 \%$ in emissions with BD derived from waste olive oil. These results disagreed with those of Utlu and Koçak (2008) and Qi et al. (2009) who found a $5 \%$ decrease in $\mathrm{NO}_{\mathrm{X}}$ with $\mathrm{BD}$. A study by Godiganur et al. (2010)which evaluated a variety of BD feedstocks also found an increase in $\mathrm{NO}_{\mathrm{X}}$ emissions. According to Al-Widyanet al. (2002), increase in $\mathrm{NO}_{\mathrm{X}}$ can be attributed to high CN of BDand its blends compared to FD. This was echoed by many other researchers (Lapuertaet al., 2008; Özgünayet al., 2007; Puhan et al., 2005). CN promotes shorter ignition delay hence prolonged combustion duration and high temperature generation which will subsequently lead to high NOx generation. Another factor is high $\mathrm{O}_{2}$ content of BD fuels. A study by Labeckas and Slavinskas (2006)revealed that maximum NOx generation was directly related to max $\mathrm{O}_{2}$ content of rape methyl ester. The increase in NOx with load can be traced to development of higher cylinder temperatures which is linearly related to $\mathrm{NO}_{\mathrm{x}}$ production. As the load is increased the engine consumes more fuel and the air fuel ratio will be increased, leading eventually to high combustion temperatures. The high temperatures are the ones which will influence $\mathrm{NO}_{\mathrm{X}}$ generation (Zhu et al., 2010; Luján et al, 2009).

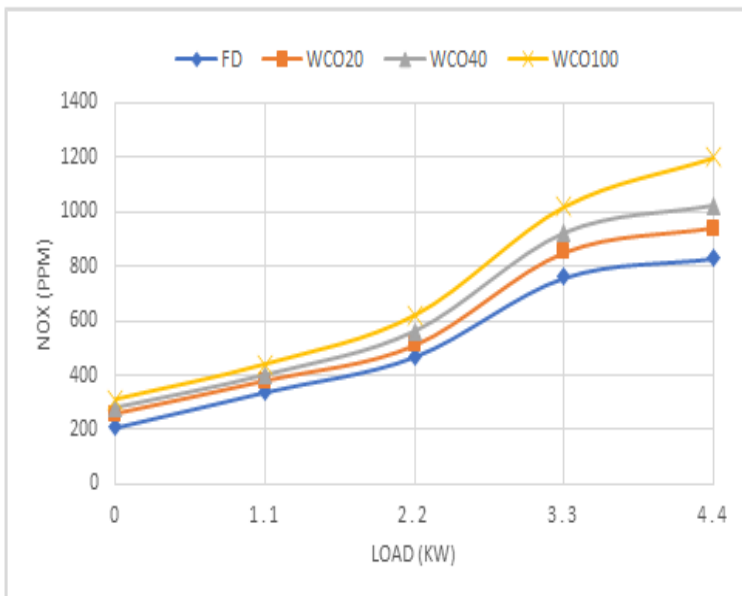

Figure 12: NOx vs Load

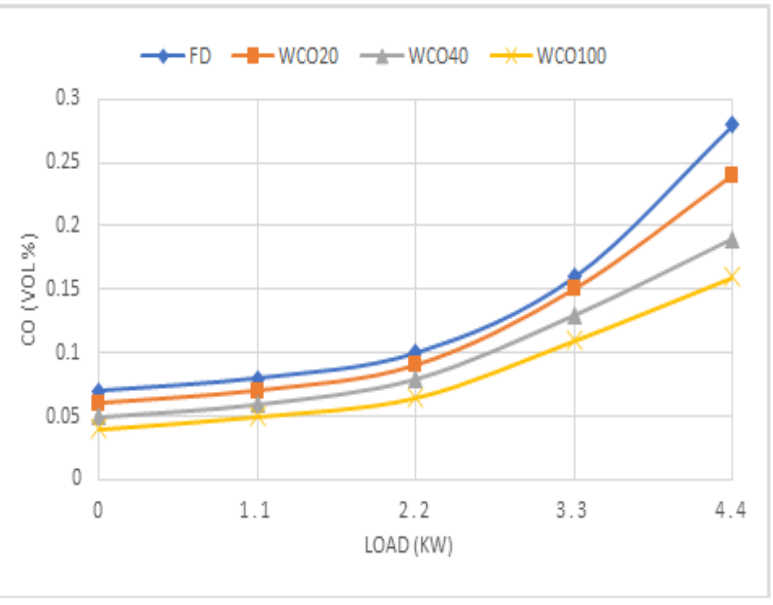

Figure 13: CO vs Load

\section{Carbon Monoxide (CO)}

CO variation with load is shown in Figure 13. CO increases with load and WCO and its blends depicted lower trends in comparison to FD. WCO and its blends contain higher $\mathrm{O}_{2}$ content compared to FD which promotes complete oxidation. An increase in WCO proportion in the blend showed a reduction in $\mathrm{CO}$ emissions. The highest reduction of $62.5 \%$ was found with WCO100 at $100 \%$ loading. $\mathrm{CO}$ is generated in fuel rich zones where there is $\mathrm{O}_{2}$ defiance. WCO and its blends have extra $\mathrm{O}_{2}$ available to suppress formation of $\mathrm{CO}$ compared to FD fuels. Higher $\mathrm{CN}$ also causes shorter ignition which will ultimately prolong combustion and promote conversion of $\mathrm{CO}$ to $\mathrm{CO}_{2}(\mathrm{Ha}$ et al., 2019). A study by Krahl et al. (2003)showed a reduction in CO of $50 \%$ with rape seed derived BD compared to that of FD. Astudy by Raheman and Phadatare (2004)with Karanja derived BD and its blends (B20, B40, B60, B80) revealed a reduction in CO of $94 \%$. Ozsezen et al. (2009) performed an evaluation of WMPOME and found that CO was reduced by $86.89 \%$. Puhan et al.' (2005)results showed a reduction of $30 \%$ in CO when compared with FD. However, research by Fontaraset al. (2009)showed an in increase in CO of 54\% with B5O compared to FD. The same researchers also founda decrease in $95 \%$ with B100 compared toFD although the researchersdid not offer reasons for thesefindings. The reduction in $\mathrm{CO}$ has been attributed to higher $\mathrm{O}_{2}$ content which promotes complete combustion. $\mathrm{CO}$ is generated in oxygen deficient portions of the 
combustion chamber. This is reduced with $\mathrm{BD}$ since it has high $\mathrm{O}_{2}$ content compared to FD. High $\mathrm{CN}$ has also been pointed as an influencing factor in CO reduction. A study by Wu et al. (2009)revealed that a decrease in CO correlates with an increase in $\mathrm{CN}$.

\section{Unburnt hydrocarbon (UBHC)}

Variation of UBHC with loading isshown in Figure 14. There is an increase in UBHC with load. The results were similar to the results by Wu et al. (2009) who performed experiments with different types biodiesel oil feed stocks with an alysis of results showing a $45 \%$ to $67 \%$ reduction in UBHC emissions. An experimental investigation by Puhan et al. (2005a)found similar results of $63 \%$ reduction in UBHC compared with FD. Another significant reduction in HC was revealed by Alam et al. (2006) who founda $60 \%$ reduction in HC compared to FD fuels. UBHC are generated at fuel rich zones of the combustion engines. $\mathrm{BD}$ contains higher $\mathrm{O}_{2}$ content compared to FD and this will be utilized for complete combustion purposes reducing generation of UBHC emissions(Choi \& Oh, 2006). High $\mathrm{CN}$ also causes reduction in ignition delay which causes longer combustion and $\mathrm{HC}$ reduction. These results disagree with those reported by Fontaras et al. (2009) and Banapurmathaet al. (2008) who reported an increment of UBHC with BD. Fontaras et al. (2009) reported a $54 \%$ increase in UBHC at $1500 \mathrm{rpm}$ with BD compared to FD which they attributed to poor engine combustion efficiency resulting from poor spray pattern from high kinematic viscosity of BD and its blends. The decreasing trend is also linear with increasing content of DB in the blend. This was similar to what was foundby Godiganuret al. (2010) who reported an inverse relationship of $\mathrm{HC}$ reduction to the BD portion increase in the blend. However, a study by Lujánet al. (2009) revealed a small decrease with B100 of $16.4 \%$ compared to B50 of $17.7 \%$. The authors attributed this to development of local air ratios which influenced high UBHC emissions generation.

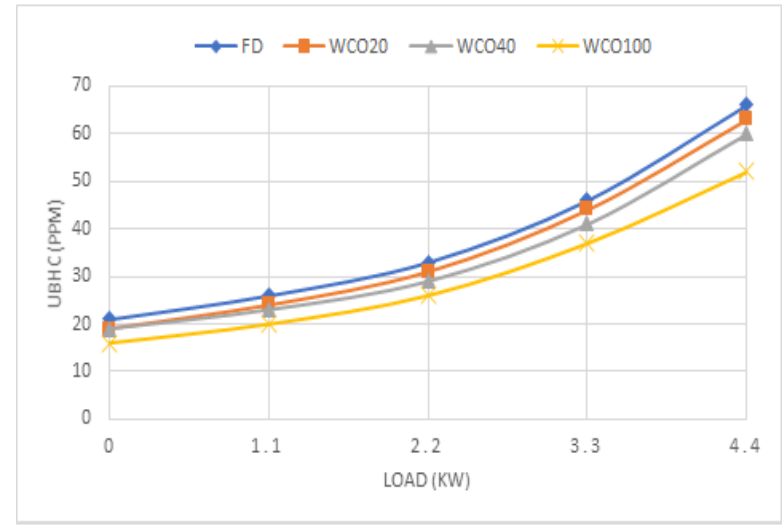

Figure 14: UBHC vs Load

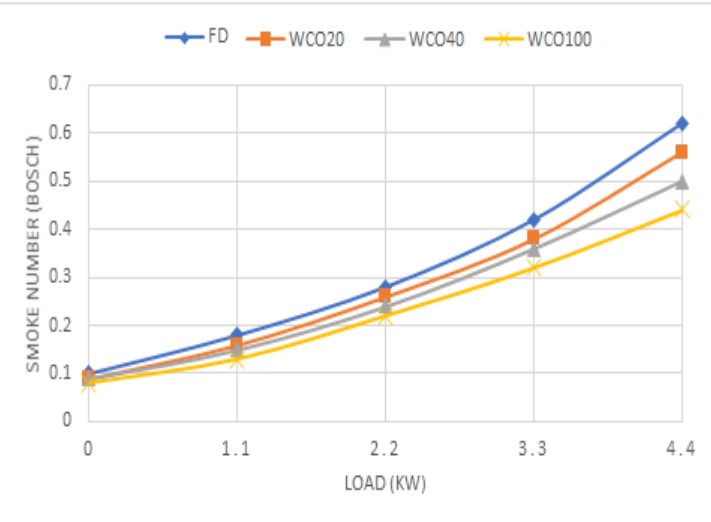

Figure 15: Smoke opacity vs load

\section{Smoke Opacity}

According to Venkatesan et al. (2017),smoke opacity isa measure of the solid hydrocarbon soot particles presentin exhaust gases of IC engines. This parameter is used to track generation of smoke within the combustion process. The increasing trend of smoke opacity with loading is shown in Figure 15. FD exhibited higher trends with load compared to WCO100 and its blends. WCO100 and its blends contain a higher content of $\mathrm{O}_{2}$ which is used for complete combustion, suppressing the generation of high amounts of smoke. According to Devan and Mahalakshmi (2009), lower kinematic viscosity which decreases the combustion process results in high smoke emission. WCO100 and its blends have ahigh CN which will promotesa shorter ignition delay. Short ignition will subsequently prolong combustion duration resulting in a better combustion process and therefore smoke reduction. 


\section{Carbon dioxide $\left(\mathrm{CO}_{2}\right)$}

Variations of $\mathrm{CO} 2$ with load are shown in Figure 16. It is self-evident from the data shown in Figure 16 that $\mathrm{CO}_{2}$ increased with loading for all fuels. A maximum increment of $21.2 \%$ was found for WCO100 when evaluated against diesel fuel. $\mathrm{CO}_{2}$ emission increased with increase in WCOBD content in the blend. According to Zareh et al. (2017), expanding $\mathrm{CO}_{2}$ gas outflows at higher loads results in an increase in fuel being injected into the combustion chamber. Various reports have associated expanding $\mathrm{CO}_{2}$ outflows at raised motor burdens to a more complete burning (Fontaras et al. 2009).Despite FD having superior $\mathrm{C} / \mathrm{H}$ ratios, it showed lower $\mathrm{CO}_{2}$ emissions. The underlying explanation behind increased $\mathrm{CO}_{2}$ emissions when compared with $\mathrm{FD}$ is that this can be attributed to increased fuel consumption resulting in higher $\mathrm{CO}_{2}$ generation as BD blends try to compensate for their lower calorific values (Ozsezen et al., 2009). Other researchers have contended that the $\mathrm{CN}$ values promote prolonged combustion process resulting in $\mathrm{CO}$ being oxidized to $\mathrm{CO}_{2}(\mathrm{Puhan}$ et al., 2005b). Varying opinions have been suggested, with others pointing to the trend of increased combustion chamber temperatures (Fontaras et al. 2009) and high density from BD and blends (Wu et al., 2009). The more satisfactory explanation related to the increase in fuel available in the chamber as the causative factor for $\mathrm{CO}_{2}$ which is similar to the trend in BSFC.

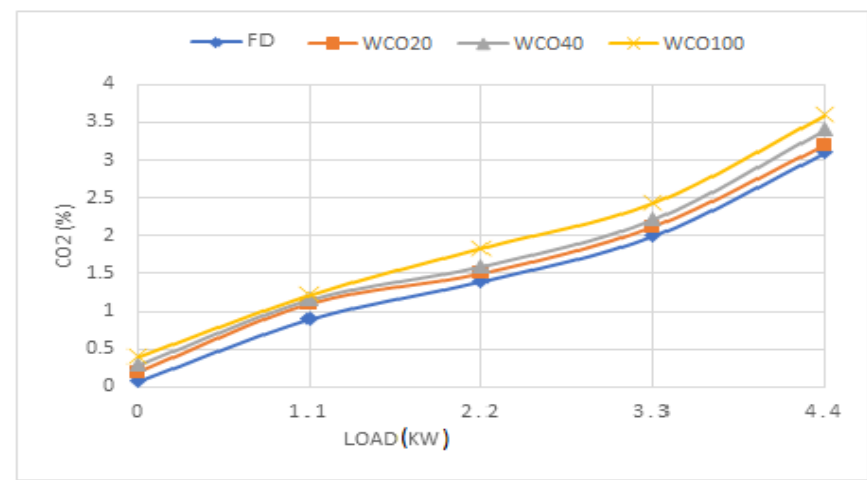

Figure 16: $\mathrm{CO}_{2}$ vs Load

\section{CONCLUSION}

This study was aimed at evaluating the viability of using WCO as an alternative fuel for a diesel engine. WCO was produced using a two-step esterification process. The parameters were optimized using the Taguchi method and found to be molar ratio $7: 1$, temperature $65{ }^{\circ} \mathrm{C}, 80$ minutes reaction time and catalyst concentration $1.5 \mathrm{wt} \%$. The optimization process pointed to reaction temperature and catalyst concentration as being the most influential parameters in BD production scoring $44 \%$ and $39.3 \%$ contribution to yield percentages respectively. Molar ratio of 7:1 and reaction time of 80 minutes scored5.4\% and $0.1 \%$ contribution to yield values respectively, signifying that reaction time has negligible effect on yield percentage determination. The BD produced conformed to ASTM D6751 standards.

When the five fuels FD, WCO20, WCO40 and WCO100 were tested in a diesel engine it was found that:

- $\quad$ BTE decreased with increased loading showing maximum reduction of $17.8 \%$ at $100 \%$ loading.

- Decreasing BTE increased with biodiesel content in the blend.

- BSFC increased with loading when compared with FD fuel revealing an increase of $27.3 \%$ and the increase correlated with the increase in WCOBD in the blend. 
- $\mathrm{CO}$ emissions decreased with load showing a reduction of $62.5 \%$ when evaluated against those of FD.

- UBHC decreased with loading and reduction of $27.2 \%$ was shown by analysis of the results.

- Smoke opacity decreased with blending and showed a reduction percentage of $34.45 \%$ when compared with that of FD.

- NOxincreased with blending,the increment being $27.3 \%$.

- $\mathrm{CO}_{2}$ increased with load and blending and an increment of $28.43 \%$ was shown by experimental evaluation.

Properties of WCO conformed to international standards ofASTM and its performance and characteristics were similar toFDtherefore it can be a viable fuel for a diesel engine. Lower blends WCO20 and WCO40 showed similar performance trends and can be utilized as alternative fuels in unmodified diesel engines.

\section{Further Research:}

- In most cases the BDproduced from the two-step trans esterification process does not conform to international standards hence addition of additives becomes a necessity for property improvement and subsequently improved performance and emission reduction.

- Performance enhancement of WCO is hereby advised as this will circumvent the performance shortfall and help in reducing exhaust emissions.

- A study involving the combined impact of other engine conditions such as compression ratio, injection pressure, and injection timing is suggested in order to gain in-depth understating of addition of WCO to diesel.

\section{ACKNOWLEDGEMENT}

The authors would like to thank the Advisor of Green Energy Solutions Research Group of University of KwaZulu-Natal, Professor Freddie Liswaniso Inambao for supporting the current research under hisCost Centre Code

\section{REFERENCES}

1. Ahmad A.L., Mat Yasin N.H., Derek C.J.C., \&Lim J.K. (2011). Microalgae as a sustainable energy source for biodiesel production: A review. Renewable and Sustainable Energy Reviews, 15(1),584-593.

2. Alam, M., Song, J., Zello, V., \&Boehman, A. (2006). Spray and combustion visualization of a direct-injection diesel engine operated with oxygenated fuel blends. International Journal of Engine Research,7, 503-521.

3. Alarcón, R., Malagón-Romero, D., \&Ladino, A. (2017). Biodiesel production from waste frying oil and palm oil mixtures. Chemical Engineering Transactions, 57, 571-576.

4. Al-Widyan, M. I., Tashtoush, G., \&Abu-Qudais, M. (2002). Utilization of ethyl ester of waste vegetable oils as fuel in diesel engines. Fuel Process Technology,76, 91-103.

5. Armas, O., Yehliu, K., \&Boehman, A. L. (2101). Effect of alternative fuels on exhaust emissions during diesel engine operation with matched combustion phasing. Fuel, 89, 438-56.

6. Ashok, B., Nanthagopal, K., Jeevanantham, A. K., Bhowmick, P., Malhotra, D., \&Agarwal, P. (2017). An assessment of Calophylluminophyllum biodiesel fuelled diesel engine characteristics using novel anti-oxidant additives. Energy Conversion and Management,148, 935-943. 
7. Atabani, A.E., Silitonga, A.S., Badruddina, I.A., Mahlia, T.M.I., Masjuki, H.H., \&Mekhilef, S. (2012). A comprehensive review on biodiesel as an alternative energy resource and its characteristics. Renewable and Sustainable Energy Reviews, 16(4),20272093.

8. Banani, R.,Youssef, S., Bezzarga, M., \&Abderrabba, M. (2015). Waste frying oil with high levels of free fatty acids as one of the prominent sources of biodiesel production.Journal of Materials and Environmental Science, 6(4), 1178-1185.

9. Banapurmatha, N. R., Tewaria, P. G., \&Hosmath, R. S. (2008). Performance and emission characteristics of a DI compression ignition engine operated on Honge, Jatropha and sesame oil methyl esters. Renewable Energy, 33, 1982-1988.

10. Carlini, M., Castellucci, S., \&Cocchi, S. (2014). A pilot-scale study of waste vegetable oil transesterification with alkaline and acidic catalysts. Energy Procedia, 45, 198-206.

11. Carraretto, C., Macor, A., Mirandola, A., Stoppato, A., \&Tonon, S. (2004). Biodiesel as alternative fuel: experimental analysis and energetic evaluations. Energy, 29, 2195-21211.

12. Chakraborty,M.,Baruah, D. C., \&Konwer, D. (2009). Investigation of terminalia (Terminalia belericaRobx.) seed oil as prospective biodiesel source for North-East India, December 2009, Fuel Processing Technology 90(12), pp. 1435-1441 DOI: 10.1016/j.fuproc.2009.06.023

13. Chhetri, A. B., Watts, K. C. \&Islam, M. R. (2008). Waste cooking oil as an alternate feedstock for biodiesel production. Energies, 1, 3-18. doi: 10.3390/en1010003.

14. Choi, S-H., \&Oh, Y. (2006). The emission effects by the use of biodiesel fuel. International Journal of Modern Physics B, 20, $4481-4486$.

15. Chumuang, N. \&Punsuvon, V. (2017). Response surface methodology for biodiesel production using calcium methoxide catalyst assisted with tetrahydrofuran as cosolvent.Journal of Chemistry, 2017, 1-9.doi: 10.1155/2017/4190818.

16. Datta, A.\&Mandal, B. K. (2016). A comprehensive review of biodiesel as an alternative fuel for compression ignition engine. Renewable and Sustainable Energy Reviews,57, 799-821.

17. David Firestone. (1989). Official and Tentative Methods of the American Oil Chemists' Society. 4th ed. Champaign: American Oil Chemists' Society

18. Devan, P.K., \&Mahalakshmi, N.V. 2009. Performance, emission and combustion characteristics of poon oil and its diesel blends in a DI diesel engine. Fuel, 88, 861-867.

19. Dorado, M. P., Ballesteros, E., Arnal, J. M., Gómez, J., \& López, F. J. (2003). Exhaust emissions from a diesel engine fueled with transesterified waste olive oil. Fuel, 82, 1311-1315.

20. Fontaras, G., Karavalakis, G., Kousoulidou, M., Tzamkiozis, T., Ntziachristos, L., Bakeas, E., et al. (2009). Effects of biodiesel on passenger car fuel consumption, regulated and non-regulated pollutant emissions over legislated and real-world driving cycles. Fuel, 88, 1608-1617.

21. Gadhave, S. L. \&Ragit, S. S. (2020). Process optimization of Tung oil methyl ester (Verniciafordii) using the Taguchi approach, and its fuel characterization.Biofuels, 11(1), 49-55. doi: 10.1080/17597269.2017.1334441.

22. Godiganur, S., Murthy, C. H. S., \&Reddy, R. P. (2010). Performance and emission characteristics of a Kirloskar HA394 diesel engine operated on fish oil methyl esters. Renewable Energy, 35, 355-359.

23. Ha, J. et al. (2019). Genome sequence of Jatropha curcas L., a non-edible biodiesel plant, provides a resource to improve seed-related traits.Plant Biotechnology Journal, 17(2), 517-530. doi: 10.1111/pbi.12995. 
24. Hansen, A. C., Gratton, M. R., \&Yuan, W. (2006). Diesel engine performance and NOx emissions from oxygenated biofuels and blends with diesel fuel. Transactions of theASABE, 49, 589-595.

25. Haşimoğlu, C., Ciniviz, M., Özsert, I., İçingür,Y., Parlak, A., \&Salman, M. C. (2008). Performance characteristics of a low heat rejection diesel engine operating with biodiesel. Renewable Energy, 33, 1709-1715.

26. Huber, G.W., Iborra, S. \&Corma, A. (2006). Synthesis of transportation fuels from biomass: chemistry, catalysts, and engineering. Chemical Reviews, 106, 4044-4048.

27. Jagadale, S. S., \&Jugulkar, L. M. (2012). Review of various reaction parameters and other factors affecting on production of chicken fat based biodiesel.International Journal of Modern Engineering Research, 2(2), 407-411.

28. Kafuku, G. \&Mbarawa, M. (2010). Biodiesel production from Croton megalocarpus oil and its process optimization. Fuel, $89,2556-2560$.

29. Kalam, M.A.,Masjuki, H.H.,Jayed, M.H.,\&Liaquat, A.M. (2011). Emission and performance characteristics of an indirect ignition diesel engine fuelled with waste cooking oil.Energy, 36(1), pp. 397-402.https://doi.org/10.1016/j.energy.2010.10.026.

30. Kansedo, J. B. (2009). Synthesis of biodiesel from palm oil and sea mango oil using sulfated zirconia catalyst. MSc Thesis, University Saints Malaysia.

31. Khalife, E., Tabatabaei, M., Najafi, B., Mirsalim, S. M., Gharehghan,i A., Mohammadi, P., et al. (2017). A novel emulsion fuel containing aqueous nano cerium oXide additive in diesel-biodiesel blends to improve diesel engines performance and reduce exhaust emissions: Part I-EXperimental analysis. Fuel, 207, pp. 741-750.

32. Knothe, G. \&Steidley, K. R. (2005). Kinematic viscosity of biodiesel fuel components:Influence of compound structure and comparison to petrodiesel fuel components. Fuel,84: 1059-1065.

33. Krahl, J., Munack, A., Schröder, O., Stein, H., \&Bünger, J. (2003). Influence of biodiesel and different designed diesel fuels on the exhaust gas emissions and health effects. SAE paper 2003-01-3199.

34. Labeckas, G., Slavinskas, S. (2006). The effect of rapeseed oil methyl ester on direct injection diesel engine performance and exhaust emissions. Energy Conversion and Management,47, 1954-1967.

35. Lapuerta, M., Herreros, J. M., Lyons, L. L., García-Contreras, R., \&Brice, Y. (2008). Effect of the alcohol type used in the production of waste cooking oil biodiesel on diesel performance and emissions. Fuel, 87, 3161-3169.

36. Lin, B-F., Huang, J-H., \&Huang, D-Y. (2009). Experimental study of the effects of vegetable oil methyl ester on DI diesel engine performance characteristics and pollutant emissions. Fuel, 88,1779-1785.

37. López, L., Bocanegra, J., \&Malagón-romero, D. (2015). Production of biodiesel from waste cooking oil by transesterification.Ingeniería y Universidad, 19(1), 155-172.

38. Luján, J. M., Bermúdez, V., Tormos, B., Pla, B. (2009). Comparative analysis of a DI diesel engine fuelled with biodiesel blends during the European MVEG-A cycle: Performance and emissions (II). Biomass and Bioenergy, 33, 948-956.

39. Martínez, J.D., Murillo, R., \&García, T. (2013). Production of carbon black from the waste tires pyrolysis. Bol.Grupo EspañolCarbón, (i), 10-14

40. Masjuki, H. H. (2014). Investigation of biodiesel production from CerberaManghasbiofuel sources. ScienceDirect Investigation of Biodiesel Production from CerberaManghas Biofuel Sources. (December). doi: 10.1016/j.egypro.2014.11.1143.

41. Mathiyazhagan, M.\& Ganapathi, A. (2011). Factors affecting biodiesel production, Research in Plant Biology: Review Article, 1(2), 01-05. 
42. Muralidharan, K.\&Vasudevan, D. (2011). Performance, emission and combustion characteristics of a variable compression ratio engine using methyl esters of waste cooking-oil and diesel blends. Applied Energy, 88,pp. 3959-3968.

43. Murillo, S., Miguez, J. L., Porteiro, J., Granada, E., \&Moran, J. C. (2007). Performance and exhaust emissions in the use of biodiesel in outboard diesel engines. Fuel, 86, pp. 1765-1771.

44. Narasimharao, K., Lee, A. \&Wilson, K. (2007). Catalyst in production of biodiesel: a review. Journal of Biobased Matter and Bioenergy, 1,pp. 19-30

45. Naylor, R. L. \&Higgins, M. M. (2018). The rise in global biodiesel production: Implications for food security.Global Food Security, 16, pp. 75-84. doi: 10.1016/j.gfs.2017.10.004.

46. Neeft, J. P. A., Makkee, M. \&Moulijn, J. A. (1996). Diesel particulate emission control. Fuel Processing Technology,47(1), pp.1-69.

47. Özgünay, H., Çolak, S., Zengin, G., Sari, Ö., Sarikahya, H., \&Yüceer, L. (2007). Performance and emission study of biodiesel from leather industry pre-fleshings. Waste Management,27, pp. 1897-1901.

48. Ozsezen, A. N., Canakci, M., Turkcan, A., \&Sayin, C. (2009). Performance and combustion characteristics of a DI diesel engine fueled with waste palm oil and canola oil methyl esters. Fuel, 88, 629-636.

49. Paper, C. \&Bilgin, A. (2015). Determination of transesterification reaction parameters giving the lowest viscosity waste cooking oil biodiesel determination of transesterification reaction parameters giving the lowest viscosity waste cooking oil biodiesel.Procedia - Social and Behavioral Sciences, 195, pp. 2492-2500.doi: 10.1016/j.sbspro.2015.06.318.

50. Pirouzfar, V., Moghadam, A. Z., Ommi, F., Omidkhah, M. R. (2008). Investigation of the effects of oxygenate and nitrate component additives on physico-chemical properties and exhaust emission of diesel fuel. احتراق وسوخت [Journalof Fuel and Combustion], 1(2). Available: http://www.jfnc.ir/article_46115_ffe16f4117808f3a39a40a97c087d3e5.pdf

51. Pirouzfar, V., Ommi, F., \&Nekofar, N. (2009). Emission and properties characteristics using additive-ethanol-diesel fuel blend on a diesel engine. Journal of Engineering,7(2), pp. 35-42.

52. Pirouzfar, V., Zarringhalam, A., \&Mirza, B. (2012). Physicochemical properties and combustion performance of Gas oil-fuel additives. Journal of Energy Resources Technology, 134(4).

53. Puhan, S., Vedaraman, N., Ram, B. V. B., Sankarnarayanan, G., \&Jeychandran, K. (2005a). Mahua oil (Madhuca Indica seed oil) methyl ester as biodiesel-preparation and emission characteristics. Biomass and Bioenergy, 28, pp. 87-93.

54. Puhan,S., Vedaraman, N., Sankaranarayanan, G., \&Bharat Ram, B. V. (2005b). Performance and emission study of Mahua oil (Madhucaindica oil) ethyl ester in a 4-stroke natural aspirated direct injection diesel engine. Renewable Energy, 30, pp. 1269-1278.

55. Qi, D. H., Geng, L. M., Chen, H., Bian, Y. Z. H., Liu, J., \&Ren, X. C. H. (2009). Combustion and performance evaluation of a diesel engine fueled with biodiesel produced from soybean crude oil. Renewable Energy, 34, 2706-2713.

56. Raheman, H., \&Phadatare, A. G. (20014). Diesel engine emissions and performance from blends of karanja methyl ester and diesel. Biomass and Bioenergy, 27, pp. 393-397.

57. Raju, V. D., Kishore, P. S., Nanthagopal, K., \&Ashok, B. (2018). An experimental study on the effect of nanoparticles with novel tamarind seed methyl ester for diesel engine applications. Energy Conversion and Management, 164,pp. 655-666.

58. Rashid, U., Anwar, F., Moser, B.R., \&Knothe, G. (2008). Moringa oleifera oil: a possible source of biodiesel.BioresoureTechnology, 99,pp.8175-8179. 
59. Rodríguez, D., Riesco, J., \&Malagon-Romero, D. (2017). Production of biodiesel from waste cooking oil and castor oil blends. Chemical Engineering Transactions, 57, 679-684.

60. Sahoo, P. K. \&Das, L. M. (2009). Process optimization for biodiesel production from Jatropha, Karanja and Polanga oils.Fuel. 88(9), pp. 1588-1594. doi: 10.1016/j.fuel.2009.02.016.

61. Song, J.-T., \&Zhang, C.-H. (2008). An experimental study on the performance and exhaust emissions of a diesel engine fuelled with soybean oil methyl ester. Proceedings of the Institution of Mechanical Engineers Part D Journal of Automobile Engineering, 222, pp. 2487-2496.

62. Tyson, K.S. \&McCormick, R.C. (2006). Biodiesel Handling and Use Guideline. $2^{\text {nd }}$ edition. U.S Department of Energy, Technical Report, DOE/GO-102006-2288.

63. Usta, N., E.Ö. Ö., \&Tорси, M. (2005). Combustion of biodiesel fuel produced from hazelnut soapstock/waste sunflower oil mixture in a diesel engine. Energy Conversion and Management, 46(5), pp. 741-755.DOI: 10.1016/j.enconman.2004.05.001

64. Utlu, Z., \&Koçak,M. S. (2008). The effect of biodiesel fuel obtained from waste frying oil on direct injection diesel engine performance and exhaust emissions. Renewable Energy, 33, 1936-1941.

65. Venkatesan, H.,Sivamani, S.,Bhutoria, K.,\& Vora, H. H. Assessment of waste plastic oil blends on performance, combustion and emission parameters in direct injection compression ignition engine.International Journal of Ambient Energy,40(2), pp $170-178$.

66. Wu, F., Wang, J., Chen, W., \&Shuai, S. (2009). A study on emission performance of a diesel engine fueled with five typical methyl ester biodiesels. Atmospheric Environment, 43, pp. 1481-1485.

67. Xuan, W.\& Leung, D. Y. C. (2011). Optimization of biodiesel production from camelina oil using orthogonal experiment. Applied Energy 88(11), pp. 3615-3624, DOI: 10.1016/j.apenergy.2011.04.041

68. Yadav, A. K., Khan, M. E., Dubey, A. M., \&Pal, A. (2016). Performance and emission characteristics of a transportation diesel engine operated with non-edible vegetable oils biodiesel. Case Studies in Thermal Engineering, 8, pp. 236-244.

69. Yan, J., Zheng, X., \&Li, S. (2014). A novel and robust recombinant Pichia pastoris yeast whole cell biocatalyst with intracellular over expression of a Thermomyceslanuginosuslipase: Preparation, characterization and application in biodiesel production. Bioresource Technology, 151, 43-48.

70. Zareh, P., Zare, A. A., \&Ghobadian, B. (2017). Comparative assessment of performance andemission characteristics of castor, coconut and waste cooking based biodiesel asfuel in a diesel engine. Energy, 139, 883-894.

71. Zhu, L., Zhang, W., Liu, W., \&Huang, Z. Experimental study on particulate and NOx emissions of a diesel engine fueled with ultra low sulfur diesel, RME-diesel blends and PME-diesel blends. Science of the Total Environment,408, 1050-1058. 
